\title{
Treasury Single Account: A Tool for Effective Cash Management in Nigeria
}

\author{
Philip Olawale Odewole \\ Department of Management and Accounting, Obafemi Awolowo University, Ile-Ife, Nigeria
}

\section{Email address:}

waleodewole@gmail.com

\section{To cite this article:}

Philip Olawale Odewole. Treasury Single Account: A Tool for Effective Cash Management in Nigeria. Journal of Finance and Accounting. Vol. 4, No. 6, 2016, pp. 328-335. doi: 10.11648/j.jfa.20160406.13

Received: September 23, 2016; Accepted: October 7, 2016; Published: November 1, 2016

\begin{abstract}
The Treasury Single Account is a financial tool that unifies all government accounts in a single pool for effective cash management. It ensures that all tax and non-tax revenues are collected from all sources and payments due are made correctly in a timely manner and that government's cash balances are optimally managed to reduce borrowing costs. TSA was introduced to bring an end to the fragmented multiple accounts kept by all Ministries, Departments and Agencies. The objective of this paper is to examine the effectiveness of the TSA as a tool for effective cash management. The research examines the objectives and benefits of TSA as a catalyst for public financial management in Nigeria. It highlights the emerging issues in TSA implementation, its operational guidelines and essential requirements of the TSA in federating states and the stakeholders responsibilities in the operation of the policy. The paper also discusses the various operational challenges facing the implementation of TSA in Nigeria and concluded that TSA as a financial tool can only achieve its desired objectives in blocking loopholes of wastages and leakages, curbing corruption and financial recklessness in ranks and file of government functionaries and enthroning transparency and probity, if government put in place enabling environment and adequate legislative supports for the smooth implementation of the policy with minimum infrastructural and technological facilities needed by the MDAs for meaningful compliance. Only gradual implementation of TSA policy can serve as a catalyst and a tool for effective cash management in Nigeria.
\end{abstract}

Keywords: Treasury Single Account (TSA), Cash Management, Public Fund and Revenue Leakages

\section{Introduction}

One of the challenges facing developing countries like Nigeria is the absence of efficient allocation of resources as well as stabilization of the business cycles within the domestic economy. The lack of a solid unified structure of government banking as an important factor for efficient management and adequate control of government's cash resources is another debacle.

Government's banking arrangements designed to minimize the cost of its borrowing and maximize the opportunity cost of cash resources was non-existent. Nigerian government could not accurately account for total public fund available in different Ministries, Departments and Agencies. A large proportion of the public fund allocated to MDAs for both capital and recurrent expenditures, lodged in various commercial banks were loaned back to the governments at outrageous bank interests. MDAs operated fragmented multiple accounts with various commercial banks, warehousing public funds which were neither traceable to nor disclosed to the Central Authority at the end of each accounting year but masqueraded into fictitious accounts. The cost of governance was skyrocketing in a weak economy with a sorry state of infrastructure which demanded urgent government interventions in a quick succession.

The Ministry of Finance and the Accountant General's Office lack a unified view and centralized oversight control over government's cash resources, thereby, created a scenario where cash lies idle for extended periods in numerous bank accounts held by MDAs while the government continued to borrow to execute its budget.

The government therefore, was left out with no other option than collapsing all operating accounts of all MDAs domiciled in various Money Deposit Banks with their credit balances into a Single Pool of Account to form a Pyramid of fund. 
The idle cash balances in bank accounts of the MDAs failed to earn market related remuneration needed for growth. The government being unaware of these unspent resources, incurs borrowing costs from the commercial banks, to fund its operations and developmental projects. The idle balances are used freely by Money Deposit Banks to extend credits to the owner-government to finance implementation of its annual budgets.

These idle balances instead of being returned to the covers of the government, became a deal instrument between the government officials and the financial institutions, in most of the times. These observations, therefore, formed the basis for the emergence of financial revolution in Nigerian government accounting system termed TSA, which was designed to tame corruption, enthrone transparency in the handling of public fund and enhance effective cash management in public life

In the exercise of his executive power under section 80 and 162 of the 1999 Constitution of the Federal Republic of Nigeria (as amended) which presumes that all revenues expended are captured in the national budget and are authorized by the National Assembly, the President, in August, 2015, issued out a directive, mandating all Federal Ministries, Departments and Agencies to implement the Treasury Single Account and all MDAs that are yet to comply should close all revenue accounts maintained in different banks or branches and transfer the proceeds to the TSA maintained by the Central Bank of Nigeria.

\section{Conceptual Definition of Treasury Single Account (TSA)}

TSA is a bank account or a set of linked accounts through which the government transacts all its receipts and payments. It is an essential tool for consolidating and managing government's cash resources, therefore, minimizing borrowing costs [1] It is a unified structure of government bank accounts enabling consolidation and optimal utilization of government cash resources.

It is a single tool for harvesting revenue inflows of Ministries, Department and Agencies (Eme and Chukwural). [2]

Treasury Single Account shares some important features:

- All governments accounts should be unified, merged, collapsed into a single pool of account to enable the Ministry of Finance and the Accountant - General's Office exercise oversight function over the entire government inflows and out flows. This unified structure of government bank account will facilitate fungibility of all cash resources and management of government's fund.

- All Ministries, Departments and Agencies are not allowed to open, operate and transact with any other accounts with the commercial banks apart from the TSA open and designated for the agency.

- All MDAs cash balances from both budgetary and non- budgetary resources are consolidated and brought together into TSA. All public funds irrespective of its sources, are passed and integrated into the TSA. All Public funds shall be under the instance close watch of the Government functionaries and ministries of Finance. [3]

\section{Overview of Treasury Single Account}

The introduction of the Treasury Single Account in Nigeria started in 2012 under President Goodluck Jonathan. But not much was known about it until 2015 when President Muhammadu Buhari took over the reigns of governance and the full-fledged implementation of TSA took effect with all the Federal Government Ministries, Department and Agencies. Prior to the full-fledged introduction and implementation of TSA, Nigeria paraded fragmented multiple banking systems for her inflows and outflows. There were unreasonable numbers of fragmented bank accounts in multiple banks with various Money Deposit Banks which made both the oversight function and the establishment of government consolidated cash position at any point impossible. The idle cash balances held in MDAs accounts were not disclosed when government went borrowing the fund it originally owned from the commercial banks at ridiculous interest (Obinna, 2015). [4]

By law, all the MDAs in Nigeria are expected to remit $25 \%$ of her inflows generated from all the Internally Generated Revenue sources apart from the proceeds of Revolving Fund Accounts which were designated exclusively to finance consumables with the MDAs. In 2012, about $\$ 120$ billion was reported to have been collected by government from the MDAs as $25 \%$ remittances of their gross revenue to the national treasury while a sum of $\$ 34$ billion was collected as remittable fund in 2013 [5] (Yusuf, 2016). Despite the fact that many MDAs defaulted in their remittances to the Consolidated Revenue fund (CRF), the $25 \%$ remittances collectible from the MDAs were substantial in monetary value. [6]

The Audit Report in 2008 by the Revenue Mobilization and Fiscal Commission indicted many Deposit Money Banks in Nigeria for failure to remit the revenue collected on behalf of the Federal Government from both the Custom Service and Federal Inland Revenue Service (Harusu, 2015). [7]

In a circular dated August, 2015, President Buhari approved the establishment and operation of Treasury Single Account for e-collection of Government Receipts for all Federal MDAs. In other words, all receipts due to Federal Government or any of her agencies are expected to be paid into this Single Account so as to aid transparency and facilitates compliance in line with sections 80 and 162 of the Constitution of the Federal Republic of Nigeria 1999 (as amended). The introduction of the TSA therefore brought to an end the operation and maintenance of fragmented and multiple accounts of all the MDAs and the creation of a unified Single Accounts where the proceeds of the all Federal Government, and her agencies are kept under the close watch of the Government Functionaries. All operating, existing fragmented accounts kept by the MDAs are outlawed and 
became unoperational. [8]

\section{Objectives of Treasury Single Account (TSA)}

The e-collections scheme is a comprehensive electronic solution for the remittance, management and reporting of all Federal Government receipts (revenues, donations, transfers, refunds, grants, fees, taxes, duties, tarrifs etc.) into the TSA and sub-Accounts maintained and operated at the Central Bank of Nigeria with the following objectives:

- to ensure total compliance with the relevant provisions of the 1999 constitution of the Federal Republic of Nigeria (section 80 and 162);

- to collect and remit all revenues due to the Federation Account and Federal Government Consolidated Revenue Fund.

- to block all leakages in government revenue generation, collection and remittance. It facilitates better coordination with monetary policy implementation.

- to enthrone a new regime of transparency and accountability in the management of government receipts.

- to improve on availability of funds for developmental programmes and projects (it prevents the idle balances being maintained in multiple account).

- to align with the Central Bank of Nigeria's cashless policy.

- to minimize transaction costs during budget execution. It facilitates reconciliation between banking and accounting data. It enhances efficient control and monitoring of funds allocated to various government agencies. These objectives were reported by Central Bank of Nigeria Monetary Policy Committees meeting to advance the course of Treasury Single Accounts in Nigeria.[9]

Benefits of Treasury Single Account (TSA)

Sialendra and Israel (2010) outlines the benefits of TSA in the IMF working paper as follow: The benefits of TSA were clearly outlined in the International Monetary Fund (IMF) working paper in 2010 [10] as follows:

- It allows complete and timely information on government cash resources. The introduction and implementation TSA makes an integrated Financial Management Information System (IFMIS) with adequate interfaces available in real time. Updated government cash balances are available on daily basis.

- It improves appropriation control. The TSA ensures that the Ministry of Finance and the Office of the Accountant - General of the Federation have full control over budget allocations, and thereby strengthens the authority of the budget appropriation. It is an important factor in managing and controlling government's cash resources. It ensures that all tax and non-tax revenues are collected and payments are made correctly in a timely manner and government's cash balances are optimally managed to reduce borrowing costs.

- It reduces the debt servicing costs and eradicates financial misappropriation in the public sector.

- It facilitates better fiscal and monetary policy coordination, reconciliation of fiscal and banking data and improves the quality of fiscal information.

- It improves operational control during budget execution.

The introduction and implementation of TSA will allow the Ministry of Finance and Office of the Accountant General have full information about cash resources and this will, in effect, makes adequate planning and implementation of budget execution in an efficient, transparent and reliable manner, possible.

- Enables efficient cash management. A TSA facilitates regular monitoring of government cash balances, it allows the government to identify causal factors of variances and distinguishes causal factors from random variances in cash balances which is crucial in fund management and effective cash monitoring in public sector fund management [11].

- It reduces bank fees and transaction costs. The implementation of TSA in government circles reduces the aggregate number of bank accounts operated by the MDAs and in effect, leads to cover administrative cost for the government for maintaining these accounts, including the costs associated with bank reconciliation and reduced banking fees.

- It facilitates efficient payment mechanisms for MDAs. A TSA arrangement within the economy makes it possible to monitor payment mechanisms. It leads to lower transaction costs and removes ambiguity regarding the volume of the location of the government funds. It eliminates "float" in the banking and payment systems and imposes transparent fee and penalty structures for payment services.

- It improves bank reconciliation and quality of fiscal data. A single pool of account system allows for effective reconciliation between the government accounting systems and cashflow statements from the banking system. It improves the timeliness and quality of the fiscal account and greatly reduces the risk of errors in reconciliation processes.

- It lowers liquidity reserve needs. A treasury single account reduces the volatility of cashflows through the treasury and therefore allowing for maintenance of a lower cash reserve/buffer to meet unexpected fiscal volatility. It minimizes borrowing costs, brings an end to fragmented multiple accounts and enhances effective control of Government inflows [12].

The benefits of the implementation of TSAs are showcased in its ability to ensure availability of funds for the execution of government policies, programmes and developmental projects, it controls aggregate cashflows within fiscal and monetary limits; it improves management of domestic borrowing programme, directs the investment of idle funds, 
improves transparency and accountability of all Federal Government of Nigeria receipts; and encourages the consolidate $d$ view of government cash position. One of the benefits of the TSA is in the reduction of the wave of endemic corruption, obstructing pilferages in public places, destroying the pipelines of wastages and mismanagement and enthroning transparency and probity in corporate spending [13].

\section{Emerging Issues in the Implementation of TSA}

(a) Operational Guidelines for the Implementation of TSA Essential Requirements of the TSA in Federating States. The Implementation of TSA in Nigeria is primarily designed to bring all government funds in bank accounts within the effective control and operational purview of the Treasury, with the following requirements imposed on all MDAs:

(i) Government agencies are not to operate any bank accounts under any guise, outside the purview and oversight of the Treasury.

(ii) The consolidation of government cash resources should be comprehensive and encompass all government cash resources, both budgetary and extra-budgetary.

(iii) Government banking arrangement should be unified to enable the relevant government stakeholders such as the Ministry of Finance (MF) and the Accountant General (AG) have full oversight of government cash flows across bank accounts.

(iv) There are two TSA models: (1) The main TSA and associated ledger sub-accounts are to be maintained in a single banking institution or (2) The main TSA is maintained in a single banking institution and associated zero balance ledger sub-accounts (ZBAs) are maintained in other institution from where balances are swept daily to the main TSA in CBN or the appointed main TSA hosting financial institution.

(v) Each state Government shall select any TSA model of its choice. The choice of a TSA model shall be informed and guided by the availability of clear operational processes and basic technology infrastructure that supports the implementation of the model of choice.

(vi) Each state government shall inform the Governor of the Central Bank of Nigeria of its decision to introduce the TSA scheme, detailing, the states preferred TSA model (banking structure) and level of preparedness to commence, operate and support the scheme, which shall include, but not limited to project organization and resourcing, operational process work flow, available technology infrastructure.

(vii) Each state government shall ensure that all legal framework, extant laws, cash management processes and policies, financial regulations, Treasury Circulars, etc. are put in place to guide the TSA operation, as well ensure that, clear information is regularly issued to relevant internal and external stakeholders before, during and after the commencement of the TSA scheme.

(viii) Each state government shall maintain contractual agreement(s) with parties involved in the design, delivery and ongoing support of TSA scheme. Such agreement shall clearly define the terms and the roles and responsibilities of the state government and the relevant parties, such stakeholders may include, but not limited to the CBN, Deposit Money Banks, Payment Technology Solution Providers etc.

(ix) Each state government shall have a clear and unambiguous position of all outstanding debts owed Deposit Money Banks (inclusive of debts incurred by its MDAs) before the commencement of the TSA scheme. Where a state is unable to fully liquidate its debts with DMBs before the commencement of the TSA, it shall put in place a firm repayment schedule, before commencing the TSA scheme with the CBN.

(x) Each state government shall establish a TSA project team to be led by an official not below the position of a Director in the Public Service, to coordinate the implementation of the state's TSA initiate. The team shall have primary responsibility for coordinating all pre-implementation, implementation and postimplementation programme required for the successful implementation of the state governments TSA scheme. This shall include but not limited to organizing sensitization, user training, change management, risk management, project reporting etc.

(xi) Each state government shall undertake a comprehensive review, harmonization and update of its financial and treasury management process, procedures and systems, as may be necessary, to support the successful implementation and operation of the TSA initiative.

(xii) Each state government shall be responsible for the provision of adequate sustainable capacity and resources at different levels across all MDAs.

(b) Stakeholders' Responsibilities in the Operation of TSA

The main stakeholders and their roles in the operation of TSA are highlighted below:

1. Ministries, Departments and Agencies (MDAs)

The expected roles of the MDAs for the successful implementation of TSA in Nigeria are:

(i) Ensure that their revenue targets are met

(ii) Provide their payers with details of payment including accounts and nature of payment

(iii) Guide payers on e-collection processes including how to pay at the banks or through other channels of the CBN payment gateway (Remita). 
(iv) Where applicable, ensure that appropriate services are rendered upon confirmation of payment

(v) Monitor their payers and collecting banks to ensure that payments are actually made.

(vi) Undertake regular reconciliation of all collection accounts

(vii) Render revenue returns to the office of the Accountant - General of the Federation on a monthly basis

2. The Responsibilities of the Deposit Money Banks on TSA Operation

(i) Ensure that their duties under the subsisting payment gateway (MOU) are effectively discharged.

(ii) Ensure that customers making payment to government are given prompt service.

(iii) Ensure that all collection in favour of government are promptly remitted.

(iv) ensure that operational and other relevant issues are logged authorities (OAGF, CBN and REMITA) without delay.

(v) Liaise regularly with OAGF to ensure smooth operation of the e-collection initiative.

(vi) Cooperate with relevant Department of OAGF and $\mathrm{CBN}$ in respect of MDAs accounts closure, transfer of funds to MDAs accounts at $\mathrm{CBN}$, collection, monitoring and reporting.

3. The Roles of the Central Bank of Nigeria on TSA Operation

(i) To provide payment gateway platform

(ii) Development of overall e-collection and e-payment policies for the nation.

(iii) Interfacing with Deposit Money Banks (DMBs) and monitoring them.

(iv) Creation and maintenance of bank account including CRF/TSA, FAAC, and TSA sub Accounts.

4. Role of the Office of the Accountant - General of the Federation (OAGF)

(i) Ensure effective implementation e-collection

(ii) Development of operational guidelines

(iii) Proper monitoring of the collection gateway

(iv) Prompt reconciliation of all collection

(v) Support MDAs, banks and payers for smooth operation of e-collection

(vi) Regular monitoring of all collections to ensure that they are promptly remitted and accounted for.

(vii) Issuance as well as continuous review and update of the e-collection guideline and processes.

(viii) Abide by the provisions of the MOU with $\mathrm{CBN}$, Service Providers and Banks.

5. The Role of the Service Providers in TSA Operation

(i) Work with $\mathrm{CBN}$, OAGF and other stakeholders to articulate systems requirements.

(ii) Provide a robust, stable and effective integrated processing platform

(iii) Ensure the optimal availability of all relevant systems and platforms

(iv) Provide effective and efficient support to users of all platform

(v) Provide users with relevant reports

(vi) Training of users on the use of the payment gateway.

(c) TSA Control Mechanisms

(i) The operation of the TSA e-collection initiative is designed to be monitored by all relevant agencies, including the office of the Accountant - General of the Federation (OAGF), Budget Office of the Federation (BOF) and office of the Auditor-General for the Federation to ensure that MDAs comply with the relevant government financial management provisions, as well as the TSA implementation guideline.

(ii) Central Bank is responsible for monitoring of all linked accounts to TSA at the CBN, compliance of banks and other financial institutions with the CBN guidelines on the implementation of TSA as well as ensuring that withdrawals limits are enforced.

(iii) $\mathrm{CBN}$ is also responsible for daily transfer of funds from the sub-accounts to the CRF/TSA based on instructions from the OAGF.

(iv) Categorization of MDAs for Federal Government TSA/e-collection scheme.

Ministries, Department and Agencies were categorized and implementation strategies were spelt out for various categories for TSA implementation compliance as follows

Table 1. Categorization of Ministries, Departments and Agencies for Federal Government Tsa/ E-Collection Scheme.

\begin{tabular}{|c|c|c|c|}
\hline S/No & MDA Category & Examples & Implementation Strategy \\
\hline 1. & $\begin{array}{l}\text { MDAs fully funded through the } \\
\text { Federal Government Budge }\end{array}$ & $\begin{array}{l}\text { All Ministries, } \\
\text { Departments, Agencies and } \\
\text { Foreign Missions }\end{array}$ & $\begin{array}{l}\text { (i) All collections from these Agencies to be paid directly into the CRF/TSA } \\
\text { (ii) Expenditure to be driven from CRF/TSA based on Annual Budge }\end{array}$ \\
\hline 3. & $\begin{array}{l}\text { MDAs not funded through the } \\
\text { Federal Budget but expected to } \\
\text { pay operating surplus } 25 \% \text { of } \\
\text { Gross Earning to the CRF }\end{array}$ & $\begin{array}{l}\text { CBN, SEC, CAC, NPA, } \\
\text { NCC, FAAN, NCAA, } \\
\text { NIMASA, NDIC, NSC etc. }\end{array}$ & $\begin{array}{l}\text { (i) All collection from these agencies to be paid into sub-accounts at CBN, } \\
\text { which are lined to TSA } \\
\text { (ii) Platform will be configured to allow access to funds in the sub-accounts } \\
\text { based on approved budget. }\end{array}$ \\
\hline
\end{tabular}




\begin{tabular}{|c|c|c|c|}
\hline S/No & MDA Category & Examples & Implementation Strategy \\
\hline 4. & $\begin{array}{l}\text { MDAs that are funded from the } \\
\text { Federation Account }\end{array}$ & $\begin{array}{l}\text { NNPC, FIRS, NCS, } \\
\text { MMSD, DPR }\end{array}$ & $\begin{array}{l}\text { (i) All Federation revenues generated by these Agencies to be paid into the } \\
\text { Federation Account at CBN } \\
\text { (ii) All Independent Revenue generated by these Agencies to be paid into } \\
\text { CRF/TSA } \\
\text { (iii)FGN share of Federal Account to be paid into CRF/TSA } \\
\text { (iv) Statutorily approved cost of collection to be deducted from Federation } \\
\text { Account and paid into sub-accounts at CBN which are linked to TSA }\end{array}$ \\
\hline 5. & $\begin{array}{l}\text { Agencies funded through the } \\
\text { special Accounts (Levies) }\end{array}$ & $\begin{array}{l}\text { NSC, RMRDC, PTDF, } \\
\text { NITDA, etc. }\end{array}$ & $\begin{array}{l}\text { (i) Sub-Accounts linked to TSA to be maintained at CBN } \\
\text { (ii) All IGR collected to be directly paid into the CRF/TSA } \\
\text { (iii) Platform will be configured to allow access to funds in the sub-account } \\
\text { based on approved budget. }\end{array}$ \\
\hline 6. & $\begin{array}{l}\text { Profit oriented Public } \\
\text { Corporations/Business } \\
\text { Enterprises }\end{array}$ & $\begin{array}{l}\text { BIO, NEXIM, BOA, } \\
\text { Transcorp Hilton etc. }\end{array}$ & (iv) Dividends from these agencies to be paid into the CRF/TSA \\
\hline 7. & $\begin{array}{l}\text { Revenue generated under Public } \\
\text { Private Partnership }\end{array}$ & $\begin{array}{l}\text { All incomes from PPP } \\
\text { arrangements e.g. } \\
\text { production of international } \\
\text { Passports, Seaport, } \\
\text { Concession Arrangement. } \\
\text { Drug Revolving Funds, } \\
\text { (Teaching Hospitals, } \\
\text { Universities) fertilizer } \\
\text { revolving funds, Roll-Back } \\
\text { Malaria, SURE-P etc. }\end{array}$ & $\begin{array}{l}\text { (i) Project Account (revolving Funds) to be maintained at CBN. } \\
\text { (ii) Collection (IGR) from these agencies to be paid to CRF/TSA. } \\
\text { (iii) Platform will be configured to allow access to funds in the sub-accounts } \\
\text { based on approved budget. }\end{array}$ \\
\hline
\end{tabular}

The table shows the summary of the ministries, departments and agencies in Nigeria in different categorization in-line with their sources of funds in the process of implementing treasury single account, stating the accounting system to adopt and the types of account to be maintained in various government collections and inflows of public funds accrued to them.

\section{Practical Challenges in TSA Implementation}

The introduction and implementation of TSA in Nigeria is bedeviled with severe challenges which have potentials to undermine the overall success of the financial policy. Some the challenges are enumerated below:

The first challenge in implementation of TSA is the inability of the MDAs to carryout timely reconciliation of Accounts. Every organization has a statutory duty to keep close watch on its bank account transactions to guard against fraud or the infiltration of extraneous entries. It exerts the watch through regular preparation of bank reconciliation statements. Reconciliation is the process of resolving the difference between the balance as per cashbooks and the balances as per bank statement on the same date and in respect of the same items of transactions.

Unfortunately, since the introduction and implementation of the TSA in Nigeria, many MDAs find it difficult, and mostly if not impossible, to carryout timely reconciliation of the TSA account. The reason partly being that, many of the institutions operated fragmented multiple accounts before the implementation of TSA. With TSA, all the credit balances in these different accounts have been mopped up to a single account opened in the name of the MDAs while for internal control purposes, the MDAs still keep open these multiple accounts. Apart from this, some of the MDAs, especially the Teaching Hospital, Medical Centres and Universities etc. operate Revolving Fund Accounts whose activities attract inflows and outflows from these funds, procurement of consumables and other related operating issues are being managed by different revolving fund committees. Revolving fund accounts are purpose fund accounts established with a seed fund and the proceeds from this fund are wholly and exclusively expanded on the procurement of the consumables that will make the fund revolve with time.

In compliance with Federal Government directive, that all MDAs fund - balances of the revolving fund account inclusive, were transferred to the TSA open for the institution. Segregating the various accounts for accounting and reconciliation purposes become impossible. TSA created a scenario whereby MDAs have a heap of fund generated from different sources with huge balances without identifiable particular account that warehouses the fund. Besides, many MDAs cannot even update their cashbooks not alone reconciling their accounts.

Secondly, cashbook entries in respect of cash payments and receipts are expected to be made and postings should be balanced each day, cash balances are to be confirmed on a daily basis. The regular checking of the cashbook is an important exercise in detecting errors and frauds. The physical cash balance has to be viewed daily and specification certified in the cashbook by the close of the office. The Head of the Posting Unit will undertake confirmation of the postings in the cashbook with the details of the relevant payment vouchers, latest on the following working day. Payment vouchers will be scrutinized to contain the arithmetical accuracy of the gross amounts deductions and the net figures. This is one of the fundamental function of the treasury office. However, the implementation of TSA has wiped off all these statutory accounting procedures in 
many MDAs. Inflows and outflows are mopped up together into the TSA. Some MDAs cannot access their accounts to obtain current balances not alone printing the bank statements. Until recently, MDAs still sent mandates to Central Bank of Nigeria before payments are processed into the beneficiary's accounts.

More also, there is an acute challenge in the preparation of weekly financial statements and rendition of returns and accounts with the implementations of TSA. It is one of the statutory duties of the central pay office/treasury services of the MDAs to prepare weekly financial position of the organization for management's use. The operating activities, financing decision and investment decisions of the organization are based on the weekly financial position. Also, the supervising ministries, expect the MDAs to render monthly, quarterly and annual returns and reports of the organization summarized into inflows and outflows and the releases and disbursements of the statutory allocation on various sub-heads. The implementation of TSA has made impossible the timely rendition of various returns and accounts. Statutory allocations are haphazardly done without direction. Allocation are released into wrong platforms which is capable of misleading the MDAs to render uninformed and false accounts and reports.

Furthermore, the sudden take-off of the TSA operations inline with the presidential directive is another headache to the MDAs. The take-over time was hurriedly concluded without regard to the level of technological infrastructure available with the MDAs. The deadline was imposed on the MDAs with sanctions for defaults when they were most unprepared. The basic take-off infrastructure needed for a minimum successful operation of the policy like computer systems, trained personnel etc. were not provided for.

The uncooperative attitude of the Deposit Money Banks coupled with their unwillingness to transfer the public funds held in "trust" for the MDAs to the TSA open for the institution was a bitter peal. Many commercial banks engaged in secret and illegal dealings with some of the MDAs top echelons to conceal public funds under fictitious private accounts. Some of them generated phony accounts names that did not carry the MDAs name to fraudulently prevent the fund from being transferred to the TSA for the institution. Where transfers were effected, the values of fund transferred to TSA were deflated and different from the amounts appeared on the banks statements of the MDAs. Worse still, wrong entries were made in sequence, in the process of transferring fund to MDAs' TSA. The process was flawed with errors of original entries and without due diligence- The money meant for a particular MDAs was transferred to another MDAs and the reversal of entry or recovery of same was made technically cumbersome, while the unwillingness of the affected MDAs to release the strange fund to the rightful owners, is a big issue.

The TSA guideline provides a broad legal framework and it does not address the operational details and peculiarity of some MDAs. Some MDAs have financial autonomy granted to them by legislation including powers to maintain a fund from which to pay expenses and even to invest surplus funds and maintain a reserve. Some MDAs generate revenue in various foreign currencies and TSA framework does not provide for disclosure of exchange difference accounting in their respective annual reports. The project fund attracted to some MDAs by lecturers and medical consultants denominated in foreign currencies, mistakenly mopped up with the MDAs fund still remained unrecovered in many institutions. Some of the MDAs are still battling to resolve mopped up fund in the office of the Accountant-General of the Federation.

The full implementation policy has fisted harsh liquidity crisis on the banking sector, which is the engine room of the economy. This liquidity problem has disabled the banks to lend to the private sector for real sector development and enhance the productive capacity of the economy.

\section{The Way Forward}

The Federal Government should consider the possibility of a gradual implementation of the TSA as a panacea for a better performance in order to prevent a policy summersault. The banking sector has been completely stripped of funds. This has caused untold hardship to the entire citizenry. An orderly migration of cash balances from commercial bank accounts to the TSA should be a better option to prevent the bandwagon effects on the economy. This, also should be complemented with adequate monetary policy measures. The legal framework of the TSA operation should be reviewed and amended where necessary to take into accounts the peculiarity of the operations of some MDAs.

The availability of adequate technological facilities should be a condition precedent for the MDAs full implementation of the TSA scheme. Also, adequate training and workshops should be organized by the office of the Accountant-General of the Federation and the Ministry of finance for all the stakeholders, public officers, bank officials and civil servants. The idea of putting the horse before the cart will be counter- productive for the desired results intended for the policy. Tax authorities should use the opportunity to start presenting robust tax revenue reporting to include tax collections by tax types, industry sectors, states, number of tax payers, demography, tax credits, unpaid refunds, values of tax incentives granted and so on. The FIRS and Joint Tax Board should fast-track the implementation of their e-fillings projects which should help ultimately in ensuring that instant credits are granted to tax payers for remittances to TSA via commercial banks.

The liquidity crisis effect of the Money Deposit Banks should be cushioned, so that the commercial banks can perform its intermediation roles both to the private sectors and the public at large. There should be policy reversal of the sudden migration of public fund from the commercial banks so that the banks can generate credits to stimulate the economy.

The budget office and the Accountant- general's office should provide useful information to all the MDAs on the 
fundamentals and basics of TSA as it affects the operations of MDAs, banking arrangement and the general payment system and patterns in the domestic economy.

Government should establish a transitional arrangement from the present multiple accounting systems to the TSA arrangement whereby effective monitoring techniques will be enforced by the CBN on the implementation manuals of the TSA to all the stakeholders and MDAs.

TSA policy took effect in Nigeria in the middle of the year without regards to subsisting accounting systems and existing payment arrangements in place. Ordinarily, most major changes that can affect changes in accounting dates are better introduced and implemented at the beginning of the fiscal year to make allowance for the variability in the operation throughout the year.

The role of the CBN and the Deposit Money Banks in the operation of the TSA should be properly defined to prevent overlapping functions and conflict of interest by the banks. Also, the stakeholders' responsibilities in TSA implementation should be clearly indicated and spelt out in the manual.

The government should guide and protect banks' liquidity position to prevent monetary policy crises in the financial sector. This can be achieved in the orderly movement of funds from the Money Deposit Banks to the TSA without distorting monetary policy equations.

\section{Conclusion and Policy Recommendation}

The objective of this paper is to x-ray the contents of TSA as a policy thrust to combat misappropriation of fund and its effectiveness as a tool for cash management. In order for the policy to achieve its aims and objectives the following are the policy recommendation:

Government should embark on extensive public enlightenment among the stakeholders and the general public. There should be awareness programme that will bring about the benefits to be derived from the policy to both the government and the generality of the populace.

The TSA policy is a desirable one in Nigeria especially in this era of executive lawlessness, misappropriation and wastages of public fraud. The policy will go a long way to curb corruption in high places and enshrine transparency to ranks and files of public officials.

National workshops and seminars should be organized on geo-political basis to accommodate all the government functionaries, public servants, bank officials etc to stress the need and the benefits in the implementation of TSA

The implementation of the TSA should be in phases for effective monitoring and compliance. A 'state-jacket' implementation for the whole country at the same time may not bring desired results.

Government should create appropriate enabling environments and legislative supports for the policy to bring about desired success and intended goals.
Government should make available infrastructural facilities and technological equipment for the MDAs for effective take-off of the policy in their respective locations.

A gradual transfer of public fund from the Money Deposit Banks to the TSA seems to be a more welcome development than a sudden withdrawal of fund from the commercial banks that can spark up liquidity crisis in the banking industry and cripple economic development. Only a properly tailored and monitored TSA policy can achieve its desired purpose and serve as an effective tool in cash management.

\section{References}

[1] Adeolu, I. A. (2015) 'Understanding the Treasury Single Account (TSA) System - Things You Should Know.”Business and Economy, Market Development.

[2] Eme, O. I., D. C. Chukwarah, and E. N. Iheanach (2015) "Analysis of Pros and Cons of Treasury Single Account Policy in Nigeria". Arabian Journal of Business and Management Review (OMAN) vol. 5 (4): 20-39.

[3] CENTRAL BANK OF NIGRIA (2015) "Revised Guildelines for Compliance with Treasury Single Account by Banks in Nigeria”. Pp 32-38.

[4] Obinna, C. (2015) "'Banks Face Liquidity Strain as Federal Government Enforces Treasury Single Account," Thursday Paper, August 11, p. 52.

[5] Yusuff, M. B. (2016) "Effects of Treasury Single Account on public Finance Management in Nigeria". Research Journal of Finance \& Accounting, Vol. 7 (6): 164-170.

[6] Guardian Editorial (2015) "Buhari on Treasury Single Account, Guardian, August, 28, Pp. 16.

[7] Hamisu, M. (2015) "MDAs, Banks under Pressure as TSA Deadline Ends" Daily Trust, September 14. P. 3.

[8] Williams M. (2010) "Government Cash Management: Its Interaction with Other Finance Policies. Technical Notes and Manuals (Washington: International Monetary Fund).

[9] Central Bank of Nigeria (2014) "Communique No 94 of the Monetary Policy Committee Meeting”, March, $24^{\text {th }}-25^{\text {th }}$, Pp. $1-37$.

[10] SailendraPattanaya and Israel Fainboim (2010) "Treasury Single Account: Concept, Design and Implementation Issues" - IMF Working Paper. 10/143 (Washington: International Monetary Fund).

[11] Khan, A and M. Pesson (2010) "Conceptual Design: A critical element of a Government Financial Management Information System, Project Technical Notes and Manuals, (Washington, International Monetary Fund).

[12] Lienert, Ian (2009) "Modernizing Cash Management, Technical Notes and Manual. Fiscal Affairs Department, Washington: International Monetary Fund.

[13] Okwe, M. (2015) Treasury Single Account: Giving Life to Jonathan's Dead Policy Directives, Guardian. Sunday, 16 August, p. 14. 